Crime, Histoire \& Sociétés / Crime, History \& Societies

Vol. 22, $n^{\circ} 1 \mid 2018$

Varia

\title{
Rethinking the origins of the Sicilian Mafia. A new interpretation
}

\section{Francesco Benigno}

\section{(2) OpenEdition \\ Journals}

Electronic version

URL: http://journals.openedition.org/chs/2143

DOI: $10.4000 /$ chs. 2143

ISSN: 1663-4837

Publisher

Librairie Droz

Printed version

Date of publication: 31 October 2018

Number of pages: 107-130

ISSN: 1422-0857

\section{Electronic reference}

Francesco Benigno, "Rethinking the origins of the Sicilian Mafia. A new interpretation", Crime, Histoire \& Sociétés / Crime, History \& Societies [Online], Vol. 22, n¹ | 2018, Online since 31 December 2020, connection on 14 January 2021. URL: http://journals.openedition.org/chs/2143 ; DOI: https://doi.org/ $10.4000 /$ chs. 2143 


\title{
Rethinking the origins of the Sicilian Mafia
}

\author{
A new interpretation
}

\author{
Francesco Benigno'
}

\begin{abstract}
This article seeks to ground the study of the origins of the mafia in the context of nineteenth-century Italian politics. The approach taken is to link changes in discourse with the processes by which criminal figures were identified, controlled, classified, represented and (eventually) made part of folklore. Such an approach involves linking the literary imagination of the nineteenth century with political context and with the theory and practice of the criminal justice system as they combined to define crime in public discourse.
\end{abstract}

Cet article vise à mettre au jour les origines de la mafia dans le contexte politique italien du XIX siècle. L'approche retenue consiste à lier les changements dans le discours avec les processus par lesquels les criminels étaient identifiés, contrôlés, catégorisés et (finalement) construit comme une composante du folklore. Une telle approche implique de lier l'imagination littéraire du XIX siècle avec le contexte politique ainsi que la théorie et la pratique du système judiciaire, qui ensemble définissent le crime dans le discours public.

\section{INTRODUCTION}

$\mathrm{T}$ he Sicilian mafia, one of the world's most notorious and influential criminal organisations and progenitor of the powerful American mafia, has engendered a lively debate (both academic and popular) about its nature. Traditional interpretations, however, have not analysed in depth the question of the origins of the phenomenon: influenced by a folkloric perspective they have mainly presented the formation of this criminal organization as coming from a mythical past and/or being closely linked to archetypal traits of Sicilian culture. More recent research analysing the twentieth-century mafia has scarcely addressed the question of its origins. In these works, the mafia has been often assumed as pre-existing, a form of historical immanence, and hence its formation has remained unexamined. Thus, the nineteenth-century mafia has been predominantly considered as a mere premise and antecedent of the twentieth-century criminal organisation.

This article presents the conclusions of a broader research project that has focused on the formation of Italian criminal groupings in the period of national unification. ${ }^{2}$ The perspective adopted here interprets the discourse about mafia as a part of the

1 Francesco Benigno is Professor of Modern History at Scuole Normale Superiore, Pisa, Italy. He has research specialisms in organized crime, revolutions and revolts in modern history, and violence and terrorism.

2 Benigno (2015).

Crime, Histoire \& Sociétés / Crime, History \& Societies 2018, vol. 22, n 1, p. 107-130 
public rhetoric of that time, and as something very influential in the cultural shaping of criminal groups. According to this interpretation, the gangs that were called mafia in Sicily do not appear as antagonists of the newly-constituted political order (and therefore external to it) but rather as one of its components. Mafia, therefore, should not be seen as a threatening wild shrub growing outside the fence of public order but as a domestic plant, whose growth participates to its construction.

\section{SICILIAN STIGMATA OR ENTREPRENEURIAL ACTIVITY?}

For many years, from the latter part of the nineteenth century until the middle of the twentieth, the mafia has been considered an aspect of traditional Sicilian culture, the manifestation of an extreme propensity for individual, anti-authoritarian assertiveness. This trait was regarded as a distinctive, very peculiar, Sicilian way of being and of behaving. ${ }^{3}$ Such a tradition was set in train by Giuseppe Pitrè (18411916), the celebrated ethnologist and the father of research on Sicilian folklore, who, writing in the middle of the nineteenth century, noted that in the Borgo quarter of Palermo the adjective mafiusu was used to indicate a man who was "handsome" and, by extension, "courageous" and "enterprising". ${ }^{4}$ Over time the word came to be used to indicate resolute men ready to resist bullying of any kind. Later, used as a noun, it came to indicate those who, through the use of physical force, were able to impose their will on others. The word mafia more generically indicated this frame of mind, which Gaetano Mosca called the "mafia spirit" or the "mafia mentality", 5 something which had its roots in insularity, in self-assertion, and in a distrust of constituted authority.

As late as 1925, this identification of mafia with traditional Sicilian culture was strong enough to induce Vittorio Emanuele Orlando, the Sicilian politician who had been Italy's Prime Minister from 1917 to 1919, to assert provocatively that he himself should be considered a mafioso. In opposing the Fascist regime, which had launched an anti-mafia campaign which was actually aimed at undermining the strength of Liberal supporters and their power groups, he stated:

If mafia is understood to mean a sense of honour taken to the extreme, a total rejection of all abuse of power and of all bullying, a nobility of spirit which stands up to the powerful and favours the weak, a commitment to friendship which is stronger than death itself, if mafia means such feelings and such attitudes, even when they are taken to excess, these are specific characteristics of the Sicilian soul and hence I proudly declare myself to be a mafioso. ${ }^{6}$

For Leonardo Sciascia, perhaps the most renowned Sicilian writer of the second half of the twentieth century, the mafia was above all a way of being in the world and a way of viewing it, which was rooted in a heightened sense of insularity which went by the name of sicilitudine, and which, in his writings, became a metaphysical

\section{Brancato (1986).}

4 Pitrè $(1875$, p. $289-90)$. Previous to Pitrè there is the testimony by Giacomo Pagano $(1875$, p. 41$)$ who noted, amongst the populace and in the jails of Palermo, the spread of the word mafia meaning excellence or even superiority.

5 Mosca (1900, p. 236-7). On the etymology of the word, See Benigno (2015, p. 215, note 72),

6 Cited in Brancato (1986, p. 231-6). 
category of the human condition. ${ }^{7}$ It is obvious that conceiving the mafia in this way, as an archetypal trait of Sicilian culture, has no bearing on the question of its origins. If the mafia is understood to be a given mental disposition typifying the Sicilian way of thinking, then one may trace its origin back to any period one likes: to the time of Spanish rule, to Arabic domination in the Middle Ages or even to Roman times. ${ }^{8}$

This notion of the mafia as being part of an indigenous cultural tradition exists alongside its identification with the island's backwardness. Sicily's determined resistance to modernising changes was considered as a direct consequence of the mafia's anti-modern culture, which effectively hindered or even blocked the island's chance of joining the move towards progress. From this perspective, the key to the uniqueness of the mafia was to be found where the secret of Sicilian insularity supposedly lay - in the vast, desolate expanses of western and central Sicily which were the undisputed domain of large cereal-growing estates and of agrotowns marked by endemic violence. These were the rural environments where anti-modern values tenaciously survived: the attention to precedence, the refusal to provide information to or collaborate with constituted authority (omertà, the so-called code of silence), and notions of morality and altruism that were limited to the family and rooted in a sense of honour. More recently, re-examinations and re-evaluations of this tradition in anthropologically-oriented studies have, despite a sophisticated perspective, nevertheless continued to stress the central role of some features of traditional culture in creating the typical mafioso. ${ }^{9}$

Since the 1970s the massive increase in the visibility of organised crime (due to its enormous profits from the construction industry and from drug trafficking) have rendered the traditional linking of the mafia and underdevelopment obsolete and have changed the emphasis of studies. The proven ability of the Mafiosi gangs to accumulate wealth has forced historians and social scientists to abandon the paradigm of the mafia as bearing the legacy of a bygone world, and to examine its capacity to change, to create its own space in the modern world, and to prosper. ${ }^{10}$ Similarly, its origins were no longer sought in the backward rural parts of Sicily dominated by the legacy of feudalism, but in the cities and in the intensively farmed coastal areas. In other words, the mafia was no longer seen as a factor representative of and creating backwardness, but as an element, albeit controversial, of the island's difficult journey towards modernisation. The question of explaining the specific nature of the mafia phenomenon assumed a central role in the resulting, productive debate in which the notion prevailed of the mafia as a dynamic phenomenon, closely linked to changes in Sicilian society, and open to innovation. The mafia was accordingly studied in its entrepreneurial role and in its complex links to violence and capitalist accumulation. ${ }^{11}$

This approach, which offered a virtually new paradigm, was much influenced by the revelations provided by the pentito [informant] Tommaso Buscetta, which were as important as the information about the American mafia provided by Joe Valachi in 1963. Buscetta's revelations made it possible to draw up a detailed organisational

Sciascia (1994).

8 See, for instance, Titone (1964), Cancilla (1984), Tranfaglia (1991), Renda (1984-86).

9 Hess (1973), Blok (1974 and 2002), Schneider (1976).

10 Catanzaro (1988, 1993, 1995).

11 Pezzino (1990a), Gambetta (1993), Lupo (1993), Mangiameli (2000), Dickie (2004). 
chart of a criminal organisation which was based in, and controlled, western Sicily and which went by the same name as the American mafia-Cosa Nostra.

\section{DANGEROUS CLASSES}

After the Buscetta revelations, the piovra (octopus) immediately ceased to be a figure of the imagination and a basically literary construct, and became (in the public mind at least) something brutally real, an organised secret society. The impact of this "discovery" was also felt in the field of scholarship. The question of the origins of the criminal phenomenon called the mafia, whether it was seen as springing from a culture of backwardness or as characterised by the gradual onset of modernity, necessarily had to be reconfigured. A retrospective vision emerged which, looking at the past through the present, identified the mafia as a deeply-rooted and longstanding criminal organisation. In one of his early interviews as an informant, Buscetta exemplified this new way of seeing things by rejecting as unrealistic the traditional notion of the mafia which he defined as a fiction, mere literature. ${ }^{12}$

However, it may well be that literature is actually a valid starting point from which to reconsider, after a certain lull in interest, the problem of the origins of mafia. Those living in the second half of the nineteenth century - in the period when the new Italian state was being created and when for the first time a criminal phenomenon came into view and was given a name - were immersed in a way of imagining the world which was basically literary, and it was only through literature that a secret society could be conceived and a criminal or conspirator could be imagined.

Opposing this view and in keeping with recent trends which emphasise a cultural approach to the history of crime,,$^{13}$ this article aims to analyse what was written about the mafia during the nineteenth century and to study these writings in isolation from what would later be written. This approach avoids the anachronism of seeing the visions of the mafia developed in these discourses as mere premises and antecedents of the twentieth-century criminal organisation that we are familiar with. The intention here is to restore the semantic polyvalence of the contexts in which these thoughts were expressed and, in particular, to restore public order as the fundamental point of reference of their discursive register seen essentially in the political sphere. From these writings there emerges a concept of public order which, rather than being seen as protecting civil society from the threats of organised crime, was seen as defending the established political order from threats of subversion. The result was that criminal organisations, instead of being the antithesis of public order, were actually a potential (even if hidden) support for it.

Obviously, there were "dangerous" elements that needed to be controlled, but, for reasons of expedience, they could be also manipulated and organised against the subversives who were jeopardising constituted order with their threats of violent regime change. ${ }^{14}$ It follows that the problem of the origins of the mafia needs to be placed not in a different cultural tradition, which transmitted alternative values, regressive or modern, but in the same cultural ambience and in the same realm of

\footnotetext{
12 Arlacchi (1995). See also Barrese (1993) and, in English, Shawcross and Young (1987).

13 See, inter alia, Wiener (1990), Leps (1992), Gregoriou (2012), Kalifa (1995, 2005).

14 Tombs (1980).
} 
literary imagination which shaped the methods of the police and of the judiciary which characterised the nascent national state..$^{15}$

Such an approach has the advantage of reconnecting the study of the mafia to the broader European theme of collective insubordination and of the criminal propensities of the popular strata which, using a term which became widespread in the 1840s, were defined as "dangerous classes". ${ }^{16}$ Fifty years ago Louis Chevalier resurrected the term in a famous book that gave centre stage to the question of the emergence in France, in the first half of the nineteenth century, of a popular subjectivity which was disorderly, subversive and criminal, and which was the sinister double of the emerging working class. ${ }^{17}$ In Chevalier's opinion, the great names of French literature who, from Sue to Balzac and Hugo, had depicted this world of Bohemian and debauched Parisian dropouts and could provide a privileged means of gaining knowledge about a world which the new discipline of statistics had begun to quantify but had failed adequately to capture. ${ }^{18}$

Nowadays it is impossible to share Chevalier's optimistic confidence in the claim of realist literature to give an exact representation of reality and so to use it as a key to unlock the behaviour of the urban proletariat. However, this is not to say that his insight should be dismissed. The appeal which the depiction of the world of the bas-fonds then exerted on the general public did indeed mark a major turning point in popular culture. ${ }^{19}$ The criminal class was born, romantically perceived as a separate and autonomous popular subgroup differentiated from the bourgeois world by possessing not only its own traditions and lifestyle but also its own language, the argot. ${ }^{20}$ It was also distinct from the working class, of which it was the obnoxious and malign counterpart.

Nevertheless, after Chevalier's celebrated book, the subject of "dangerous classes" received little attention from historians. ${ }^{21}$ This is part of a more general neglect of the relations between criminal figures in the public imagination and the building of the political order. In the case of Italy, a number of studies have linked the rise of the mafia to the process of national unification, the Risorgimento. ${ }^{22}$ Attention focused mainly on the persistence of revolutionary traditions, which, latent in the period of conspiracies, had supposedly provided elements of the new "violent bourgeoisie" with a training in politics and in the control of public resources. In this perspective, the mafiosi of the zone around Palermo had been vectors of types of rebellious action which the tradition of conspiracies had codified, such as the capacity to organise squads of picciotti (lads) who had shown their mettle throughout the Risorgimento and had re-emerged during the Expedition of the Thousand (1860) by which Garibaldi had united Sicily and southern Italy to the new Kingdom of Italy. ${ }^{23}$

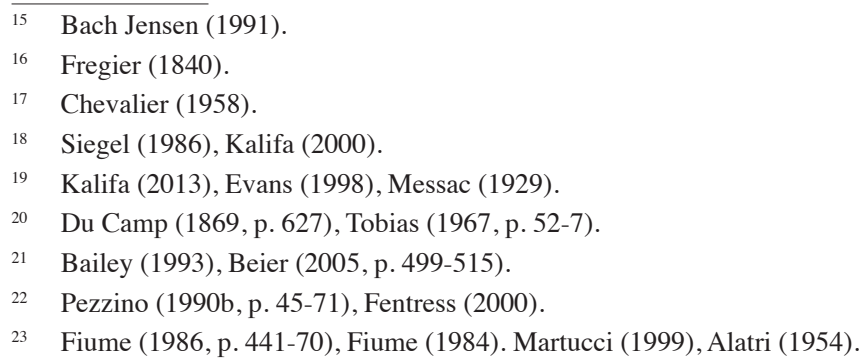


Part of the reason for this relative lack of interest - not only in the Italian casein the "dangerous classes" was the rise (during the latter decades of the twentieth century) of the social sciences, which came to occupy a position at the confluence of various disciplines - psychiatry, criminal law, anthropology and social psychology. Social sciences' interest for the fin de siècle world, and the ways in which "deviance" was fabricated, actually precluded the possibility of looking at the entire nineteenth century, at what the subject of "dangerous classes" had implicitly highlighted and at what criminology tended for the most part to ignore - the nexus, which was obvious despite all attempts to conceal it, between politics and crime.

Historians have often done little but restate the contrast (already familiar in contemporary arguments) between the London Metropolitan Police, which developed ever greater expertise in fighting crime and thus won for itself a reputation for political neutrality, symbolised by the popularity of the "Bobby", and the French police, which, at least until the Third Republic, had the characteristic of being a haute police, political police. It goes without saying that this primacy of the political use of the police is linked to a context - continental Europe - where absolutist and despotic regimes were prevalent for much of the nineteenth century, and where there was a widespread obsession with the question of subversion. Reality was much more complex, however, and even Liberal and constitutional regimes on occasion adopted police methods used by authoritarian regimes, such as organising criminals to defend constituted authority, and the concomitant practices of infiltration and of diversion, of control of the press and of manipulation of public opinion. Even in the case of the United Kingdom, the nexus between the fight against crime and the defence of the political order becomes more evident if one turns aside from the metropolis and looks instead at the management of public order in places such as Ireland with its Fenians ${ }^{24}$ and India with its Thugs. ${ }^{25}$

An analysis of the origins of the mafia along these lines, as the present article attempts, also provides an opportunity to rethink the degree of "dangerousness" of the "dangerous classes", and to highlight their profoundly political nature, an obvious phenomenon in the period which witnessed, before it had been formally acknowledged, the birth of the figure of the "modern criminal".

\section{THE INVENTION OF MAFIA}

The first uses of the terms mafia (or maffia, as it was then more frequently called) and mafioso go back to the early 1860 s, shortly after the unification of Italy. Significantly, as in the case of camorra, the use of the adjective preceded that of the noun. The term mafioso (in Sicilian mafiusu, or even maffiusu), is to be found in the title of a play of 1863, Li mafiusi di la Vicaria which was to enjoy considerable success. ${ }^{26}$ In the play the authors (the actors Giuseppe Rizzotto and Gaspare Mosca) depicted gaoled criminals who adopted the typical tactics of those who then went by the name of camorristi.$^{27}$ Like all prisons in the Romantic period, Bourbon prisons

\footnotetext{
24 Betterworth (2010).

25 Benigno (2011, p. 97-120).

26 Risotto (1994), di Bella (1991).

27 Benigno (2013).
} 
were not only places of privation but were also characterised by two other specific elements. ${ }^{28}$ One was the marked tendency of the prison authorities to co-manage public order by relying on the collaboration of individuals belonging to the criminal world. Tens, and at times hundreds, of prisoners lived in gloomy dormitories. To avoid brawls and other acts of violence, the Bourbon warders made use of criminals with a reputation for bullying and skilled in the practice of violence. In return for maintaining some sort of order inside the gaol, these "special" prisoners, the camorristi, were allowed certain privileges, the chief of which was the right (at times in league with the wardens) to oversee the lucrative activity of gambling. They also enjoyed the right to demand that newcomers pay a kind of illegal tax. These camorristi, who in Sicily were beginning to be called mafiosi, also adopted other tactics, such as imposing a fee for the choice of a sleeping pallet (in theory a prisoner's right), demanding a pizzu (the term still used in Sicily to indicate protection money extorted by racketeers), or requisitioning a share of articles and foodstuffs sent to prisoners by their families. ${ }^{29}$

Such bullying was, of course, to be found in all European gaols and is reminiscent of nonnismo (the bullying of younger soldiers by older soldiers) among Italian conscripts. Although such activities did not make Bourbon gaols totally unlike present day ones, there was, however, another element which did set them apart, especially after the 1848 revolution: common criminals and political prisoners were placed in the same cells. This mixing of criminals and subversives, which became widely known in 1851 after Gladstone's denunciation of the ills of the Bourbon regime, had two important consequences..$^{30}$ One was the Neapolitan government's tendency to use criminals to control political prisoners by infiltrating the former as informers and spies who were paid to winkle out the secrets of members of conspiratorial, secret societies. The other consequence was the resulting process of acculturation or rather "political education" of common criminals. In other words, in Bourbon prisons, the worlds of criminals and patriots met, and, as a consequence, common criminals acquired the rudiments of Liberal and national political discourse.

If the first attested use of the term mafioso leads us to the world of penitentiaries and to the camorristi, the word mafia or maffia first appears (and here too the date is significant) in an official document of 25 April 1865, a report on public order drawn up by the Prefect of Palermo (Filippo Antonio Gualterio) shortly after his arrival in Sicily ${ }^{31}$ With the term mafia, the storico-prefetto ("historian and Prefect", but also "historic Prefect" as he rather affectedly liked to call himself), indicated a criminal and politically subversive secret society modelled on the literary image of the camorra..$^{32}$

Gualterio's document needs to be seen in the context of a delicate political situation. After a brief period of government by Garibaldi following the successful

\footnotetext{
28 Brombert (1975).

29 After 1851 the presence of the camorra in the Neapolitan prisons is frequently noted. See Castille (1856, p. 35-37), Vacca (1911, chapter on jail associations), Angerà (1867, p. 19), Palermo (1863) Castromediano (1895-96, p. 44, 52, 182, 229-44), Gualterio (1852, p. 267), Scialoja (1857, p, 109).

30 Gladstone (1851).

31 Gualterio to Lanza, 25 aprile 1865, see it in Archivio Centrale dello Stato, Ministero dell'Interno Gabinetto, b. 28, fasc. 282; the text has been published in De Vecchi di Val Cismon (1935-43, p. 208-15).

32 For a biographical note, see Monsagrati (2003, p. 182-186).
} 
"Expedition of the Thousand", Palermo found itself governed by a moderate majority initially linked to the Prime Minister Cavour, and later to his successors this was a political class which was bent on standardising laws for the newly-unified nation on the Piemontese model, which favoured rapid centralisation, and which was opposed to sharing power with the democratic wing of the Liberal movement. The result of this political line was that Palermo had lost its function as capital, and had been placed on the same level as the other Sicilian cities. Hence, both in Palermo and in the neighbouring provinces of Trapani, Agrigento and Caltanissetta, there was a clear decline in the strength of the leadership of the moderate Liberal front. The disillusionment created by government policy had reinforced the myth of the heroic Garibaldi and had exacerbated antipathy towards a government which should have indemnified Sicily for the ills inflicted by Bourbon despotism but which instead had become an administration which was niggardly in terms of both public investment and employment in public administration (where it was more concerned with carrying out politically-motivated purges of dissident officials and staff).

As far as public order was concerned, there was a clear tendency to equate the situation in Sicily with that of the rest of southern Italy, which was being ravaged by legitimist and religiously-inspired banditry, which left the island untouched, and, for the most part, to manage public order by using extraordinary measures. The extension of the Pica special law, with new possibilities for repression by means of administrative measures imposed without trial, such as admonition and obligatory residence, resulted in Sicily in a revival of the illiberal and arbitrary methods which had typified the Bourbon police.

The Italian government responded to these difficulties by expanding the growing militarisation of its administration, which in Sicily was resulted in the appointment of high-ranking military officers, such as Alessandro Della Rovere and Giuseppe Govone. Despite this, and perhaps because of this, Palermo was the centre of a radical Garibaldian faction, consisting basically of those who had followed Garibaldi in his ill-fated Aspromonte campaign of 1862 (a failed attempt to conquer papal Rome through a volunteer expedition) and were now anticipating some new revolutionary exploit. This was the insurrectional and Republican wing, once led by Giovanni Corrao, a former Garibaldian general, after whose mysterious death it was led by Giuseppe Badia, a former Garibaldian colonel who was in hiding because of an arrest warrant against him for threatening state security ${ }^{33}$ The threat of insurrection raised by this faction also appealed to the discontents among both those aiming at autonomy, and reactionary sectors which were either nostalgic for the former regime or were inspired by an extreme religious ideology which had been given new life by the law abolishing religious bodies.

It was in this context that alarm spread over the state of insecurity in the Sicilian countryside, to which the authorities dramatically responded by appointing to the position of lieutenant general of the Palermo division a Garibaldian general, Giacomo Medici, who had fought heroically in defence of the Roman Republic, and had been the commander of the National Guard in Palermo. With his appointment, the government attempted to split the Democratic Front in Palermo, and to create a moderate Liberal coalition able to marginalise and neutralise the democratic and radical fringes. To balance the appointment of Medici, a new Prefect arrived in the

$\overline{33}$ Falzone (1940, p. 18). 
city. Filippo Antonio Gualterio was one of the most ardent exponents of the ruling Right who, as Prefect of Genoa, had won a reputation for toughness by demonstrating his opposition on principle to any compliance with the Action Party and democratic claims. ${ }^{34}$ As the leading figure in the witch-hunt targeting opposition parties, he had repeatedly been denounced by the democratic press.

In the spring of 1865 Medici and Gualterio launched a campaign of round-ups in the rural parts of western Sicily, which involved mass arrests and extensive use of preventative measures. The huge number of soldiers deployed (15,000 men in the rural areas, 8,000 of them in the province of Palermo) were officially intended to tackle the problem of draft resistance and the consequent insecurity in the countryside around Palermo. The actual purpose was quite different: it was to "cut the grass from under the feet of the revolution", and to drain the natural reservoir of recruits for the revolt which had been proclaimed by myriad subversive groups and which, in government circles, was called "the alliance of the red and the black" (that is to say, a tactical agreement between the revolutionary Republican wing and clerically-inspired malcontents).

It is in this context that Gualterio's famous report should be placed. Writing to Lanza, his Minister, the newly-appointed and newly-arrived Prefect, who could count on his personal network of informants extending over half of Italy, attempted to indicate a clearly-defined course of action. Central to his report was his exposure of the existence of a criminal association called maffia, which had grown in strength because of "a serious and prolonged misunderstanding between nation and authority". This dissonance, Gualterio wrote, had led to two consequences: the association's "increased boldness" and the government's lack of the "requisite moral authority to ask for the necessary support of the numerous class of citizens having most influence and authority".

In the Prefect's opinion, the preventative strategy agreed with Medici and the judges to "clean up" the rural areas had the following goal: "The sole function of the operation is to entrap and to bring to justice the large number of people against whom there are warrants which have never been executed - draft resisters, deserters, former prisoners liable to punishment for contravening the conditions of release, and finally all those who have contravened admonition and surveillance orders". All these preventative measures basically aimed at tackling subversives: "fighting and, if possible, destroying the criminals would mean that the Bourbon party would be completely disarmed and rendered powerless without our becoming embroiled for the moment in political trials which, unless imposed by extreme necessity, are always a serious nuisance and, moreover, are pointless and ineffectual once surveillance has been put in place".

The passage which follows requires no further comment: "After thus carefully considering the position, I have reached the conclusion that this war should be fought in such a way that, for the moment, it would appear to be merely radical action taken against malefactors who have escaped punishment." And the revolt? The announced, feared and perhaps clumsily manipulated revolt was not to be, at least not in 1865. It would break out in September 1866, and would be a rather strange affair, without acknowledged leaders (in the meanwhile Giuseppe Badia had been arrested), and without clear political demands, despite the presence of red flags

34 Montale (1976, p. 85-173). 
and Republican slogans. The first great public debate about the mafia, born at that moment, was concerned with the causes and the responsibilities for that tragic and astonishing event.

For seven days, from 16 to 22 September 1866, Palermo had risen in arms against the young Italian state, and fierce street battles had caused hundreds of deaths. All this shocked Liberal and national opinion as Palermo was not a city like any other: it had nurtured strong anti-Bourbon conspiracies and, in January 1848, had been the first city to rise up and initiate the so-called "springtime of the peoples". In 1860 it had supported Garibaldi, it had helped to drive out the Bourbon garrison, it had become a myth of the pro-unification democratic movement. Palermo was habitually referred to as the "city of great undertakings", which was a respectful acknowledgement of its outstanding revolutionary credentials.

Then came the revolt, fed by frustration over the loss of its role as capital, by a devastating economic slump, and by the people's alienation from the rule of the Historical Right, which raised serious doubts about the viability of the young national state. ${ }^{35}$ Even if most of the armed insurgents, formed into squads, came, as had become the norm, from surrounding villages, artisans and labourers from the urban population had also taken part in the uprising. The uprising itself, despite its obvious Republican orientation, had not produced either acknowledged leaders or clear programmes. Giuseppe Mazzini, the great leader in exile of the Italian Republican movement, decried the insurrection as "anonymous" which for him meant that it was an aberration and a virtual negation of propaganda through action. ${ }^{36}$ Moreover, the revolt had also involved small groups of those nostalgic for the former regime and some sections of the clergy who resented the law confiscating the property of charitable institutions.

In this situation, the task of repression (under the command of General Raffaele Cadorna) had not one but two main goals. In addition to repressing the insurgents, there was also the problem of how to formulate an acceptable explanation for such an amazing and disturbing event. The result was the decision to proclaim a state of siege, and, at the same time, to define the uprising as the product of a clerical conspiracy to restore Bourbon power brought about through the doings of an obscure, mysterious secret society by now known as a criminal group and also as the mafia. In the words of the Crown Prosecutor Giuseppe Borsani, at the inauguration of the judicial year on 2 January 1867, the revolt had been "the uprising of the mindless plebs, greedy for blood and money, which had been manipulated by the hidden designs of the determined enemies of civilisation and of the remaining proponents of despotism and divine right" ${ }^{37}$ This insistence on the involvement of the clergy was clearly intended to rouse the solidarity of that section of Liberal opinion which saw the Church as the main obstacle remaining in the unfinished task of creating national unity. Defining the revolt as a clerical uprising carried out by criminals, and ignoring the part played by Republican agitation, was a useful way of dismissing the manifest discontent which might have been interpreted as expressing progressive and democratic aspirations and might have projected, at a national and international level, the image of a nation where insurrectionary Republican forces were able to

\footnotetext{
35 Brancato (1993).

36 Mazzini (1867, p. 207).

37 Giordano (1969, p. 258).
} 
lead a popular revolt against the monarchy. All the better if those directly involved in events, the so-called revolutionary criminal elements which had participated, could be represented as lacking any political validity, as being motivated by bestial instincts, and as bearing the blame for horrendous acts incompatible with civilised life. ${ }^{38}$

This interpretation, despite clear evidence of its unsustainability, was long supported by a fierce press campaign. Even during the sittings of the National Commission of Enquiry into the events in Palermo, Cadorna maintained his initial reading of events. The upshot was that, in the wake of the 1866 insurrection, the mafia was credited with enjoying such notoriety that this itself provided a possible interpretation of a disquieting and unexpected event. As there were no clear ideas about the mafia's nature and characteristics, the first writings about it which began to appear relied on literary depictions of the camorra, and presented the mafia as a ritualised, secret society.

Among these writings is an account of the situation in Palermo in 1865 written by the youthful geographer and anarchist Elisée Reclus, then in exile, which appeared in a well-known French travel magazine.$^{39}$ It stated that, at the very heart of the insalubrious, older district of Palermo there existed a fearsome secret criminal society called the maffia. Reclus claimed to have obtained his information from a Piemontese doctor (it is unknown whether this doctor actually existed or if he was a literary expedient) who was his guide to the "Mysteries of Palermo" and who, rather improbably, is credited with possessing first-hand knowledge about this mysterious society. The description which he gives is totally lacking in originality and essentially rehashes the descriptions of the camorra by Alexandre Dumas and Maxime Du Camp which had given it notoriety. Reclus depicted a gigantic secret society which, at the beginning of 1865 , supposedly had a membership of 5,000 who "commit themselves as a group to living on the proceeds of all kinds of deception and fraud". Just like the camorra, the maffia forced shopkeepers and artisans to pay a bounty so as to be able to carry on with their businesses: "it may be said that the whole city owes obedience to two powers: Italy and the maffia". Again like the camorra, as it was represented in contemporary descriptions, the maffia had a secret language, made up of "simple signs, gestures, furtive contacts and arcane words: the anonymity of the group provides it with a full range of methods to strike terror, and the occasional stabbing shows that it possesses its own judges and tribunals" (Reclus, p. 355).

\section{POLITICAL EXIGENCIES AND THE LITERARY IMAGINATION}

In the wake of the 1866 revolt, the maintenance of public order in Palermo was problematic, and throughout Italy there were repeated alarms created by Republican unrest. The result was a propensity to make full use of the techniques developed by the French police which were inspired by the famous formula coined in 1848 by citoyen Marc Caussidière "faire de l'ordre avec le desordre", that is, to create order

Maurici (1916, p. 454).

39 Reclus (1866, P. 356-413). 
by using the forces of disorder. ${ }^{40}$ In Italy there also existed the possibility of using the "dangerous classes" to collaborate in the management of public order. In concrete terms, this meant organising criminal groups which were allowed a measure of freedom in return for allowing themselves to be used unscrupulously to safeguard the regime against its political enemies.

The new police commissioner, Giuseppe Albanese, who like Medici (in the meantime appointed Prefect) had belonged to the section of the Garibaldian movement which had adopted a monarchic, moderate and pro-administration line, seemed firmly convinced of the usefulness, and perhaps even inevitability, of the method of co-managing order with criminality which had been widely used by the Bourbon police in Sicily. When giving evidence to the Commission of Enquiry into the events in Palermo, he had no hesitation in stating that the former regime's notorious head of police, Salvatore Maniscalco, had done well to involve "mafia leaders in guaranteeing security". ${ }^{41}$

These were not simply idle opinions as Albanese, with the concurrence of Medici, actively put these methods into practice, as the new Crown Prosecutor of Palermo, Diego Tajani, discovered to his horror. He would soon find himself challenging political authorities over arbitrary arrests, illegal detention, release of criminals on guarantees provided by prominent figures, illegal settlements in money for crimes of violence, and, above all, the widespread use of illegal methods of maintaining public order by secretly employing criminals. There was the famous case of a gang of robbers operating in the centre of Palermo who had carried out a series of daring thefts: it was discovered that their boss was an undercover policeman and a Mason with contacts both in insurrectional Republican circles and in the "clerical party". ${ }^{42}$ When Tajani, through an authoritative intermediary, complained about these methods to his Minister, he received the reply that "no one in the Ministry likes these underhand methods; they regret them but one must close an eye to many things as the Ministry holds the view that it is by this system and by organising these people that the maffia can be destroyed". ${ }^{43}$

Taviani's investigation established that, under cover of these good intentions, in practice criminals considered worthy of trust were used to combat other, dangerous criminals judged to be politically out of control; his investigation also established that men with criminal records were employed by the police forces, and that serious crimes attributable to police informers were treated with indulgence. Various pieces of evidence even concurred to indicate that the chief of police had "contracted" mafiosi to murder dangerous criminals. Tajani's struggle against these illegal methods led to a surreal outcome: an arrest warrant was issued against the chief of police and this unprecedented institutional clash concluded with the resignation of the Crown Prosecutor. All this provoked bitter and prolonged controversy in both the local and the national press. People began to talk of the existence in Palermo of a well-established modus operandi which used the mafia to maintain order. An anonymous work by a young Republican, Pietro Messineo stated: "what is at issue is not Medici or Albanese but a system"; a system based on deals done with criminals:

\footnotetext{
40 Caussidière (1849).

41 Da Passano (1981, p. 143). See also Tommasi-Crudeli (1871, p. 65).

42 Tajani (1875, p. 16).

43 Ibid., p. 15.
} 
"It was held as a dogma that, in order to curb the city's petty thieves and pickpockets, mafia men ought to be put in police uniform". ${ }^{44}$

It was in this same period that a legend, known to go back to the end of the seventeenth century, began to spread in Palermo. The legend spoke of a now defunct secret society which had been well and truly active from the sixteenth to the eighteenth century, which consisted of avengers who righted wrongs perpetrated against the downtrodden, and which went by the mysterious name of the Beati Paoli ${ }^{45}$ The organisation, as was duly noted at the time, bore an uncanny resemblance to the famous Santa Vehme, which had recently been brought back to the attention of the general public by Alexandre Dumas. ${ }^{46}$ This was an association of judges created in Westphalia at the end of the Middle Ages to deliver justice; its deliberations and its sentences were both carried out in secret. The notoriety of this secret association was cemented by Goethe, who, in the fifth act of his play Götz von Berlichingen (1773), described an impressive sitting of the mysterious court, the so-called Vehmgericht. Perhaps it was with this scene in mind that, at the end of the eighteenth century, a learned Palermitan, the Marchese di Villabianca, had written about a dark cave, which really existed in the Capo quarter of Palermo, where, according to popular tradition, the Beati Paoli met to hand down their sentences. ${ }^{47}$

Later, in the heady atmosphere of the Risorgimento, the legend had been revived and given a new slant. The romantic motif of the heroic righter of wrongs and avenger of the poor was subsumed, into the proto-nationalist theme of Sicilian resistance to the centralisation of administration in Naples. In the new national context, the theme, latent throughout the Risorgimento, emerged in a new guise as the demand for autonomy which came to the surface at politically delicate times such as the early 1870s. The decisive victory of the Catholic-Regionalist bloc in the local elections of 1868-69 altered the political and cultural climate in Palermo. It was in this period that the town council, under its new mayor (the autonomist Domenico Peranni) began to finance projects to rediscover and restore its identity as a city. Its first act was the resumption of the festino di Santa Rosalia, patron saint of Palermo. ${ }^{48}$ In this context, at the very time when Giuseppe Pitrè and Salvatore Salomone-Marino were commencing research into Sicilian popular customs, the legend of the Beati Paoli served the function of characterising the Sicilian people as naturally hostile to foreign despotism. Hence the profoundly political nature which the subject of the Beati Paoli assumed. Theirs had been

a protest perennially in arms, always hidden from the injustices and vexations of foreign governments which not only destroyed our politics and our traditional constitutions, but, on top of that, wanted by every means to turn us into Spaniards, Piemontese, or Germans. Theirs had been a protest against the privilege of the nobles and of a legal system which had always been beholden to the will of despots; and finally it had been a noble aspiration towards the independence and freedom of Sicily. ${ }^{49}$

\footnotetext{
$44 \quad$ Messineo (1871, p. 11).

45 The etymology is unclear. See the introduction to Renda (1988).

46 De Bock (1801).

47 Eco (1986, p. vii-Xxiii).

48 Cancila (1988, p. 137).

49 Renda (1984-86, p. 82).
} 
It was in these very months that the Palermo council decided to give the name of Beati Paoli to both the street and the square in front of the underground chamber which, according to tradition, had been the meeting place of the mythical society of avengers. The legend had become a reality.

In these same years, however, there were other reasons for the attention devoted to this secret society. The enactment of Law 294 of 6 July 1871 was the government's political response to the new situation created both by the fall of the monarchy in France and by fear of the International, which a ministerial circular issued to European governments by the French minister Favre on 6 June 1871 depicted as the real and most worrying danger facing them. ${ }^{50}$ Law 294 , conceived as a new "law of suspicions" and bolstered by widespread alarm about the growth of the Internationalist movement after the events in France, marked a return to the customary preventative measures: these were the "admonition" and "obligatory residence", which could be imposed on dangerous individuals, the list of whom was now brought up to date. In particular, Section 105 allowed for the police to report to the magistrate any "suspect individuals", such as "footpads, thieves, defrauders, pickpockets, receivers of stolen goods, accomplices, camorristi, mafiosi, smugglers, thugs, and all those suspected of crimes against persons or property". For the first time mafiosi were included in the list of suspects. ${ }^{51}$

In fact, no one really knew who the mafiosi were. By then the term mafioso (like camorrista) had come to indicate behaviour and propensities liable to bring discredit on the person targeted: mafioso thus came to mean not only an individual with no concern for common decency and institutions but also a bully and a thug. It had become an accusation of incivility and a term of insult. However, in the middle of the 1870 s the problem of identifying the mafia became more urgent. The liberalconservative majority, or Right, concerned about questions of its own leadership, which had come to the surface because of the increased vote of the liberal-democratic opposition in the 1874 elections, decided to make the question of public order in Sicily the testing ground of its own political viability.

\section{FORGING THE EVIL SECT}

Police activity in investigating and repressing crime in Sicily was intensified during the mid-1870s. First in Uditore, a working-class suburb of Palermo, and then in Monreale, suspect groups apparently sharing several common characteristics were investigated and placed under surveillance. For the most part they were groups organised into informal mutual aid associations with a common fund, a hierarchy, rules of behaviour and leaders. There was nothing at all unusual about this as these were the rules of association which were typical of the nascent workers' clubs which, despite their new ideology and organisation, essentially followed the older traditions of artisans' guilds and of occupational confraternities, onto which had been grafted masonic and carbonaro traditions..$^{52}$ Mutual aid societies and guild-style associations representing all workers in a particular sector were often politicised and, after 1874,

\footnotetext{
50 Romano (1954, p. 128).

51 Fozzi (2010, p. 87-92).

52 Lupo (2011, p. 42).
} 
were seen as dangerously inclined to support the Left. Hence they were viewed with suspicion, placed under surveillance, and often accused of being bases of organised criminal activity. Up until the mid-1870s, all attempts to uncover actual associations of malefactors had come to nothing. Now, a fresh attempt was made to establish a clear connection between workers' associations and the criminal world. In the context of this increased attention to all forms of collective organisation which might potentially assist Internationalist or Socialist agitation, the realisation gained ground in the police that the mafia, like the Neapolitan camorra in the past, should also be seen as a ritually organised organisation.

Relying on informers and infiltrators, law enforcement agencies came to learn of a strangely similar rite which was repeatedly found in many of the criminal groups. This was the initiation ceremony which, with some variations, has been handed down through the twentieth century until the present time. The so-called punciuta is a rite consisting, among other things, of pricking a finger and smearing the drops of blood on a holy image which is then burnt, and of taking a formulaic oath, inspired by the Masonic-carbonaro tradition, which made explicit the new member's total and irreversible commitment to the cause. Owing to the notoriety of this rite, the term punciutu, which once meant "tempted, touched" (that is, by the devil) subsequently came to be a synonym for an initiated member. As well as to the initiation ceremony, police attention was also directed to the passwords which, again in line with carbonaro traditions, made it possible to identify members of the society. These passwords, however, did not always derive from lofty, literary sources: as the Crown Prosecutor Carlo Morena showed, the main password came from an adaptation for the marionette theatre of Pasquale Bruno, a novel by Dumas with a Sicilian setting.

It is easy to explain why the police focused on distinctive rituals and means of mutual recognition. The usual preventative measures were no longer adequate to counter Internationalist-style subversion and trials for consorting with criminals were needed: this was an offence laid out in Articles 426 and 427 of the Criminal Code which punished consorting with criminals as a crime in itself, regardless of other concomitant crimes. However, the Code laid down that for such an association to exist, there must be a criminal gang composed of at least five people and that it must have an organisational structure, a hierarchy, and a sharing of the proceeds from criminal actions.

However, the laborious search for links between various groups, which would be "proved" by their having common, or at least similar, rituals and passwords needs to be put into context. A particular element of this context was the discovery in Monreale of a criminal organisation known as the Stuppagghieri and the subsequent revelation by a police spy that this had an offshoot in Bagheria (the so-called Fratuzzi gang). ${ }^{53}$ At attempt was now made to delineate the presence in Sicily of a single criminal and subversive organisation with several branches called the mafia. The Minister of the Interior was in search of arguments to legitimise the imposition of exceptional laws in Sicily at a politically-unpropitious moment - Sicily had decisively passed to the Opposition and the general elections of 1876 would see a collapse of the Historical Right which won only 4 out of the 48 seats. The Minister thus bombarded the Prefectures with requests to verify carefully what features the various gangs had

53 Crisantino (2000, p. 33). 
in common. The hypothesis of a connection linking the various criminal groups which had been identified would strengthen the idea of the existence of a programme of subversion in league with sections of the International and thus reinforce the legitimacy of the introduction of laws of exception. The matter had a manifest political relevance: the parliamentary debate on the bill for an extraordinary law on public security in Sicily, which the Government barely managed to get through after a painful parliamentary battle, prepared the way for the fall of the Historical Right in March 1876.

At the end of the nineteenth century, a policeman, Antonino Cutrera, wrote a compendium of what the police knew about organised crime in Sicily. In his opinion, the Stuppagghieri were the model type of mafia organisations. The view generally accepted at the time was that they had been organised by Giuseppe Palmeri, brother of Paolo Palmeri, the Monreale police chief, so as to create a new criminal force (a youthful mafia) in opposition to another local organisation which had become politically out of control. The judge di Menza wrote:

The police rely on informers. Who are the informers? Speaking bluntly, they are thugs and riff-raff. Well, if the informers number fifty instead of ten, if, instead of doing their spying in the dark, they rouse themselves and show their teeth on behalf of the police chief and of order, is this not the same and even better? Informers are given concessions, and concessions will be given to the enterprising young men of the new mafia. And as a result of all this, thanks to the work of the local police, there was a fine, flourishing new, young mafia which, ready for action, advanced to take on the old, local mafia. ${ }^{54}$

There was a fusion of political and criminal language - the Stuppagghieri called their opponents scurmi fitusi (stinking mackerels), and vittoriani, that is supporters of the moderate faction in power..$^{55}$

The Stuppagghieri took on the role as the genuine prototype of the mala setta (evil gang), "the central pivot of similar groups", the source spreading a secret network bound by rites and oaths, in a word, the first true cosca mafiosa (Mafia clan), appears to have been repressed by same law enforcement agencies which had created, infiltrated, protected and manipulated it. In this we have a clear example showing how the formation of criminal organisations was structured inside and not against the formal and informal system then used to manage public order.

The Monreale episode clearly shows that the mafia came into being in a context of police and judicial methods which established and regulated what was called "public order", which was virtually tantamount to political order. Two elements seemed to be required for an effective and genuine organising of crime: on one hand, a tradition of established practices involving conspiracies and secret societies and how these were represented in literature and, on the other and in parallel, the existence of methods of regulating order by which subversive criminals, and "pure" criminals as well, were identified, restrained - often they were identified in that they were restrained - and used to defend constituted order.

\footnotetext{
Di Menza (1878, p. 264).

55 Ibid., (p. 285-6).
} 


\section{SHAPING TRADITIONS}

If we take the observations about the "evil association" made in the first two decades following unification, and resist the temptation to assume that mention of a maffia or mafia must have had some basis in fact, then we can see such observations for what actually were, not straightforward descriptions or reasoned analyses but troubled warnings, alarming directives, stern injunctions, open warnings and passionate statements of contested viewpoints. Research suggests that during the period references to a criminal organisation should be understood not merely as literally denoting something but as broadly connoting something. They should be understood within a larger metaphoric, emotive, and evocative dimension, often charged with performative intentions: aimed at producing effects in the public arena and therefore essentially creative, that is, directed at influencing public opinion and the mechanisms safeguarding security. Moreover, such references relied closely on broader perceptions, shaped by literary models then current, about what a secret society was. Thus, on one hand, this view was closely linked to the discursive tradition which had shaped it and enabled it to be re-proposed; on the other, it was linked to its public/political usefulness.

As occurs in the case of travel diaries and ambassadors' reports, discourse on the subject of organised crime clearly presents a phenomenon which deserves careful scrutiny. Once a model, or a symbol or a name, has been identified, the construction of discourse tends to enter a groove, to opt for existing, ready-made pathways, to become repetitive and not infrequently to express itself in the same terms. The result is a discursive construct that only partially - and at times tangentially - relies on direct experience. The same rule applies, more or less, to both discourse on the subject of organised crime and travellers' accounts. Both are forms of discourse which are stylised and obey an inner logic of their own: their connectedness to the outside world, to "street reality", is mediated and indirect.

Historians thus face a far-from-easy choice: either they have to make a selection and "sort the wheat from the chaff" by discarding all improbable or fantastical statements (the risk is that these are the ones which fail to meet a criterion which has been created a posteriori), or they give up the idea of pre-establishing a hierarchy of discourse based on criteria which are subsequently defined. Hence, in examining writings on the mafia, one may attempt to differentiate sources and select those which seem more realistic, or else one may plunge into the semantic confusion which presents the mafia simultaneously as a hidden, shadowy organisation, a way of understanding what criminals are like, an extreme form of arrogant bullying or a mental disposition characterised by an overweening sense of one's own superiority.

Umiltà (1878) was the first to deal with the subject of camorra and mafia, contending:

when these two barbarous sounding words were first launched into the public domain [...] collective curiosity was keenly aroused. People were asking one another what these words could possibly mean. Since they first appeared in newspaper despatches from Rome, Naples and Palermo, the press has succumbed to a kind of fever mingled with scepticism and mistrust, and every journalist feels duty bound to offer an explanation of these words which has often failed to satisfy the reader. ${ }^{56}$

56 Umiltà (1878, p. 5). 
In the previous year the Sicilian Internationalist Francesco Sceusa had written a short book entitled Mafia Ufficiale, in which he had denounced official moves which had cautioned him as a mafioso so as to prevent him from carrying on his political activity ${ }^{57}$ In answer to a parliamentary question put on 17 March 1877 by Giovanni Bovio, to whom the book was dedicated, the Interior Minister Nicotera bluntly rebuffed any criticism by arguing that the terms "subversive" and "criminal" were interchangeable. As he contended, "socialists are mafiosi in Sicily, camorristi in Naples, and knife-wielding thugs in the Romagna". ${ }^{58}$ Historiography, faced by such elusive and disturbing semantic ambiguity, replete with accusations of criminality and with folkloric ballast, has hesitated to take it seriously and has adopted the attitude of attempting to discern the true from the false, distinguishing a generically arrogant attitude from a thoroughly criminal one. The resulting temptation is to study the history of organised crime by going beyond, and, in a sense, by going without, what has been said about it.

However, it is possible to adopt another approach, which is that of investigating this very confusion and, as it were, the "contamination" of the discourses, in the knowledge that that there is no underlying and pristine truth to which they refer, notwithstanding the rhetorical excesses of contradictory, concurrent and conflicting definitions. In other words, to adopt an approach which takes the reported existence of a secret organisation called the maffia as one discursive register among others. It is in this register that we find the mythic configuration of the all-powerful society as depicted by imaginative literature and by every-day experience, be it through politics, the media, the legal system or the police.

Naturally this line of investigation cannot shirk the problem of the genesis of criminal gangs which, even if they germinated in the ways described above, over time achieved partial autonomy, and availed themselves of their own independent capacity to act. For this further step to be possible, the accompanying literary and mythic discourse indicated above has a far from insignificant importance in giving form to the mafia's self-perception. Although this is ahighly complex subject which far exceeds the bounds of this article with its focus on the origins of the mafia, it is worth briefly mentioning. A short history may perhaps best illustrate this.

In April 1909, during the investigation into the murder of the Italo-American police detective Joe Petrosino, it emerged that a well-known figure, Don Vito Cascio Ferro, suspected of being himself the instigator, performed a strange and risky action which was reported to the police:

while he was a fugitive from the law he asked a man $[\ldots]$ to take a letter to a house next to a church near the Monte di Pietà in Palermo. Entrance to the house was through a small door next to the church where, once he knocked, a young deafmute woman would appear, take the letter, and open a little entrance leading to an underground chamber. She would then return from below with an answering letter containing money which she would hand him. ${ }^{59}$

The witness had recounted that, in carrying out this task, he had gone to the aforementioned place and encountered the deaf mute who had led him into the

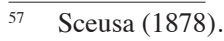

$58 \quad$ Ibid. (p. 18).

59 Montemagno (2002, p. 51-53).
} 
underground chamber, and "here he had found a gathering of quite a few sinisterlooking men, who were unknown to him. This and the presence of various tables placed in an orderly manner convinced him that this was the meeting place of criminals where stolen goods were divided out and where sentences against members were issued." The police commissioner, Ponzi, personally added in the margin of the statement that "the church in question is the Beati Paoli church in the square of that name and the house which is indicated is next to the church".

This is a baffling document, which lends itself to two possible, diametrically opposed, explanations. It may either be considered a proof of the centuries-old existence of the mafia and its descent from the legendary Beati Paoli. Or else, in keeping with the approach we are following, one may hypothesise that the mafiosi in 1909 , more than thirty years after the city council of Palermo, with a historical and political decision smacking of autonomy, opted to honour with the name of the legendary secret society, the place which housed the shadowy tribunal and in so doing enacted its own, autonomous "invention of tradition". By laying claim to the underground chamber, which was popularly believed to be the headquarters of the Beati Paoli, the city councillors, in order to strengthen and legitimise their own identity, consciously appropriated the well-known tradition of an avenging society able to right wrongs and to assist victims.

It is interesting to note that May 1909, that is, the month after these events, saw the publication in Il Giornale di Sicilia of the first instalment of the serial I Beati Paoli by William Gault, alias Luigi Natoli. The success of the novel and the resulting saga was phenomenal: "the novel became both primer and sacred text which the pater familias kept by his bed and from which, during the long winter nights, he would read, his voice choked with emotion, to his relatives and neighbours listening in religious silence". ${ }^{60}$ An indication of the novel's popularity may be seen in the statements made by the most famous mafiosi and members of other criminal organisations who became informers ${ }^{61}$ Leonardo Vitale, the first to provide information about the mafia, stated that the initiation ceremony which made a uomo d'onore replicated the "sacred rite of the Beati Paoli"; in his autobiography Joe Bonanno represented the mafia, or la tradizione as he called it, as descending from a medieval sect of avengers. ${ }^{62}$ Totuccio Contorno chose for himself the nom de guerre Coriolano della Floresta, one of the heroes of Natali's novel; and both Tommaso Buscetta and Nino Calderone showed that they believed in the line of descent of uomini d'onore from the Beati Paoli. ${ }^{63}$ Finally, during a courtroom altercation, Totò Riina and Gaspare Mutolo, "accused each other, in all seriousness, of not respecting the genuine spirit of the Beati Paoli". ${ }^{64}$

\footnotetext{
60 Eco (1986, p.xxvii).

${ }_{61}$ See, for instance, the case of Serafino Castagna: Perria (1967).

62 Fentress \& Wickham (1992, p. 187).

${ }_{63}$ Montemagno (2002, p. 51), Matard-Bonucci (1994, p. 46).

64 Gambetta (1993, p. 220).
} 


\section{CONCLUSIONS}

This article has sought to ground the study of the origins of the mafia in the context to which it rightfully belongs, that of nineteenth-century politics. Traditional historiography, when confronted by the continual overlapping of criminality and politics during this period, has chosen not to engage with this intermingling, considering it either of minor importance or a secondary effect of political rhetoric. In 1876 the scientific discipline of criminology was born with the publication of the ground-breaking L'uomo delinquente by Cesare Lombroso. ${ }^{65}$ However, the study of crime was then deemed to be quite distinct from the numerous political uses to which it was put. The reason for this was a conceptualization of crime, and especially of organised crime, as a purely "social" phenomenon and hence distinct from the discursive and practical world of politics.

The approach proposed has been to choose not to be intimidated by the medley of two types of language and of observations on crime and on politics and instead to investigate and analyse this in search of the connections, often far from obvious, which linked changes in discourse with the processes by which criminal figures were identified, controlled, classified and became part of folklore. These processes, given their performative potency, should not be taken for mere descriptions of a marginalised and deviant world but should be analysed as powerful vectors for constructing collective identities and hence of significant parts of social reality. Such an investigation is only made possible by linking the basically literary imaginaire of the time to the political struggle and to the theory and practice of the courts, ${ }^{66}$ of the police and of forensic medicine which defined crime in public discourse ${ }^{67}$

The origins of the Mafia should therefore be sought not only in the dynamic, autonomous capacities of popular strata of Sicilian society which were intent on achieving self-assertion and social advancement by the use of violence and which were generally, and romantically, imagined as a people apart, but also in their integration into the processes of constructing public order in the nascent Italian state. The result was, so to speak, a long period of training in social organisation which reached its zenith in the twentieth century, by the end of which criminal groups, by a complex process of identity creation, had achieved their own autonomy and definition. Throughout this process, these criminal groups maintained their links with public authorities and, from Sicily, came an extraordinary example of a longstanding, dangerous relationship between the world of disorder and the world of public order.

Francesco Benigno Scuole Normale Superiore Pisa francesco.benigno@sns.it

\footnotetext{
65 Lombroso (1876). On criminal anthropology, see also Montaldo (2002), Gibson (2002) and Catelnouvo (2003).

66 Jacquemet (1996).

67 Pitch (1995), Melossi, Sozzo \& Sparks (2011), Gregoriou (2012).
} 


\section{BIBLIOGRAPHY}

Alatri, P., Lotte politiche in Sicilia sotto il governo della Destra: 1866-74, Einaudi, Torino, 1954.

Angherà, F., Fuga dalle prigioni di Napoli, 2 ed., Raffaele Prete; Napoli, 1867.

Arlacchi, P., Addio Cosa Nostra: i segreti della mafia nella confessione di Tommaso Buscetta, Rizzoli, Milano, 1995.

Bach Jensen, R., Liberty and Order. The Theory and Practice of Italian Public Security Police. 1848 to the Crisis of the 1890s, Garland, New York \& London, 1991.

Bailey, V., The fabrication of deviance. "Dangerous classes" and "Criminal classes" in Victorian England, in J. Rule \& R. Malcomson, eds., Protest and Survival: Essays for E. P. Thompson, Merlin Press, London, 1993.

Barrese, O., Mafia, politica, pentiti (...) Atti della Commissiione Parlamentare d'Inchiesta sulla Mafia, Rubbettino, Soveria Mannelli, 1993.

Beier, A.L., Identity, Language, and Resistance in the Making of the Victorian "Criminal Class": Mayhew's Convict Revisited, The Journal of British Studies, 2005, 44, p. 499515.

Benigno, F., Il ritorno dei Thugs. Ancora su trasformazioni discorsive e identità sociali, Storica, 2011, 51, XVII, p. 97-120.

Benigno, F., L'imaginaire de la secte. Littèrature et politique aux origines de la Camorra (seconde moitié du XIX ${ }^{\mathrm{e}}$ Siècle, Annales. Histoire, Sciences Sociales, 2013, 68, 3, p. 75589.

Benigno, F., La mala setta . Alle origini di mafia e camorra, Einaudi, Torino, 2015.

Betterworth, A., The World that Never Was. A True Story of Dreamers, Schermers; Anarchists and Secret Agents, The Bodley Head, London, 2010.

Blok, A. The mafia of a Sicilian Village 1860-1960: a study of violent peasants entrepreneurs, Blackwell, Oxford, 1974.

Blok, A., Mafia and Blood Symbolism, in F. K. Salter, a cura di, Risky Transactions. Trust, Kinship and Ethnicity, Berghahn, New York and Oxford, 2002.

Brancato, F., La mafia nell'opinione pubblica e nelle inchieste dall'Unità d'Italia al Fascismo, Pellegrini, Cosenza, 1986.

Brancato, F., Sette giorni di Repubblica a Palermo. La rivolta del settembre 1866, Sicania, Messina, 1993.

Brombert, V.H., La prison romantique: essai sur l'imaginaire, J. Corti, Paris, 1975.

Cancila, O., Così andavano le cose nel secolo sedicesimo, Sellerio, Palermo 1984.

Cancila, O., Palermo, Laterza, Roma \& Bari, 1988.

Castille, H., Le marquis del Carretto ex ministre du Roi de Naples, II ed., Paris 1856.

Castromediano, S., Carceri e galere politiche, 2 vol., Tip. Salentina, Lecce, 1895-96.

Catanzaro, R., Il delitto come impresa. Storia sociale della mafia, Liviana, Padova, 1988.

Catanzaro, R., Recenti studi sulla mafia, Polis, 1993, 2.

Catanzaro, R., La mafia et les recherches sur la mafia en Italie, Déviance et société, 1995, 19, 2,p. 201-213.

Caussidière, M., Mémoires de Caussidière, ex prèfet de police et représentant du people, Michel Lévy frères, Paris, 1849.

Chevalier, L., Classe labourieuses et classe dangeruses à Paris pendant la première moitié du XIX ${ }^{e}$ siècle, Plon, Paris, 1958.

Crisantino, A., Della segreta e operosa associazione: una setta all'origine della mafia, Sellerio, Palermo, 2000. 
Da Passano, M., ed., I moti di Palermo del 1866. Verbali della commissione parlamentare d'inchiesta, Archivio Storica, Roma, 1981.

De Bock, J. N. É., Histoire du Tribunal secret, Behmer, Metz, 1801.

De Vecchi di Val Cismon, C.M., ed., Le carte di Giovanni Lanza, XI voll., s.n., Torino 193543.

Di Bella, S., Risorgimento e mafia in Sicilia: I mafiusi di la Vicaria di Palermo, LPE, Cosenza, 1991.

Di Menza, G., Cronache dell'Assise di Palermo, 2 voll., Tipografia. del Giornale di Sicilia, Palermo 1878.

Dickie, J., Cosa Nostra: a History of the Sicilian Mafia,Hodder \& Sloughton, London, 2004.

Du Camp, M., Clan du vol a Paris. Ses categories et ses refuges, in «Revue des deux mondes», XXXIX, 1869.

Eco, U., I Beati Paoli e l'ideologia del romanzo popolare, introduction to Luigi Natoli, I Beati Paoli, 2 voll., Flaccovio, Palerm,o 1986, I, p. VII-XXIII.

Evans, R.J., Tales from the German Underworld: Crime and Punishment in the Nineteenth Century, New Haven-London, Yale University Press, 1998.

Falzone, G., Il garibaldino Giovanni Corrao, L'appello, Palermo, 1940.

Fentress, J. and C. Wickham, Social memory, Blackwell, Oxford 1992.

Fentress, J., Rebels and Mafiosi. Death in a Sicilian Landscape, Cornell, Ithaca and London, 2000.

Fiume, G., Le bande armate in Sicilia 1819-1849: violenza e organizzazione del potere, Stass, Palermo, 1984.

Fiume, G., Comitive, bande armate, anarchia sociale e potere nella Sicilia degli ultimi Borbone, in G. Ortalli, Bande armate, banditismo e repressione di giustizia negli stati europei d'antico regime, Jouvence, Roma, 1986, p. 441-70.

Fozzi, D., Tra prevenzione e repressione. Il domicilio coatto nell'Italia liberale, Carocci, Roma, 2010, p. 87-92.

Frégier, H.A., Des classes dangereuses de la population dans le grandes villes et des moyens de les rendre meilleures, 2 tomes, J.-B. Ballière, Paris, 1840.

Frigessi Catelnouvo, D., Cesare Lombroso, Einaudi, Turin, 2003.

Gambetta, D., The Sicilian Mafia. The Business of Private Protection, Harvard University Press, Cambridge and London, 1993.

Gibson, M., Born to crime: Cesare Lomboso and the Origins of Biological Criminology, Preager, Westport (CT) and London, 2002.

Giordano, N., Storia e storiografia della rivolta palermitana del Sette e mezzo, Il Risorgimento in Sicilia, 1969.

Gladstone, W.E., Two letters to the Earl of Aberdeen, on the state prosecution of the Neapolitan government, John Murray, London, 1851.

Gregoriou, C., ed., Constructing Crime. Discourse and Cultural Representations of Crime and "Deviance", Palgrave Macmillan, Basingstoke, 2012.

Gualterio, F.A., Gli ultimi rivolgimenti italiani: memorie storiche, Le 15 Monnier, Firenze 1852, vol 1 parte II.

Hess, H., Mafia and Mafiosi: the structure of power, Lexingtons books., Lexington Mass, 1973.

Jacquemet, M., Credibility in Court. Communicative Practices in the Camorra Trials, CUP, Cambridge, 1996.

Kalifa, D., L'Encre et le sang. Récits de crimes et sociétés à la Belle Époque, Fayard, Paris, 1995. 
Kalifa, D., Les crimes de Paris. Lieux et non-lieux du crime à Paris au XIX siècle, Bilipo, Paris 2000; C. Dubois, La Bastoche. Une histoire du Paris populaire et criminel, Perrin, Paris, 2011.

Kalifa, D., Crime et culture au XIX $X^{e}$ siècle, Perrin, Paris, 2005.

Kalifa,D., Les Bas-fonds. Histoire d'un imaginaire, Seuil, Paris, 2013.

Leps, M-C., Apprehending the Criminal. The Production of Deviance in Nineteenth-century Discourse, Duke University, Durham \& London, 1992.

Lombroso, C., L'uomo delinquente studiato in rapporto alla antroplogia, alla medicina legale $e$ alle discipline carcerarie, Ulrico Hoepli, Milan, 1876.

Lupo, S., Storia ella mafia: dalle origini ai giorni nostri, Donzelli, Roma, 1993.

Lupo, S., L'unificazione italiana. Mezzogiorno, rivoluzione, guerra civile, Donzelli, Roma, 2011.

Mangiameli, R., La mafia tra stereotipo e storia, Sciascia, Calatanissetta, 2000.

Martucci, R., L'invenzione dell'Italia unita: 1855-1864, Sansoni, Milano, 1999.

Matard-Bonucci, M.A., Histoire de la mafia, Éditions complexes, Bruxelles, 1994.

Maurici, A., La genesi storica della rivolta del 1866 in Palermo, Emanuele Priulla, Palermo, 1916.

Mazzini, G., Letter to Edoardo Pantano, London 26th February 1867, Scritti editi ed inediti, vol. LXXXIV, Epistolario, vol. LII.

Melossi, D., M. Sozzo \& R. Sparks, Travels of the Criminal Question. Cultural Embeddedness and Diffusion, Hart, Oxford \& Portland, 2011.

Messac, R., La detective novel et l'influence de la pensèe scientifique, Champion, Paris, 1929.

Messineo, P., La sicurezza pubblica nella città e circondario di Palermo, Giliberti, Palermo, 1871.

Monsagratti, G., Filippo Antonio Gualterio, Dizionario Biografico degli Italiani Treccani, vol LX, Edizioni dell'Enciclopedia Italiana, Roma, 2003 p. 182-186.

Montaldo, S., ed., Cesare Lombroso, gli scienziati e la nuova Italia, Il Mulino, Bologna, 2002.

Montale, B., Filippo Antonio Gualterio prefetto di Genova, Miscellanea Storica Ligure, 1976, VIII, n.1, p. 85-173.

Montemagno, G., Luigi Natoli e i Beati Paoli, Flaccovio, Palermo, 2002.

Mosca, G., Che cos'è la mafia, in «Giornale degli economisti», s. II, XI (1900).

Pagano, G., Le presenti condizioni della Sicilia e i mezzi per migliorarle, Barbera, Firenze 1875.

Palermo, N., Raffinamento della tirannide borbonica ossia i carcerati in Montefusco, Adamo d'Andrea, Reggio, 1863.

Perria, A., Serafino Castagna. Tu devi uccidere, Il Momento, Milano, 1967.

Pezzino, P. (a) Una certa reciprocità di favori: mafia e modernizzazione violenta nella Sicilia post-unitaria, Franco Angeli, Milano, 1990.

Pezzino, P., (b) La tradizione rivoluzionaria siciliana e l'origine della mafia, Meridiana. Rivista di storia e di scienze sociali, 1990, 7-8, p. 45-71.

Pitch, T., Limited Responsibilities. Social Movements and Criminal Justice, Routledge, London \& New York, 1995.

Pitrè, G., Usi e costumi, credenze e pregiudizi del popolo siciliano, vol. II, Pedone Lauriel, Palermo 1889.

Reclus, É, La Sicile et l'eruption de l'Etna en 1865, Le tour du monde, Nouveau journal des voyages, I, 1866, p. 356-413.

Renda, F., Storia della Sicilia dal 1860 al 1970, 3 voll., Sellerio, Palermo 1984-86.

Renda, F., I Beati paoli. Storia, letteratura, leggenda, II ed. revised, Sellerio, Palermo, 1988. 
Rizzotto, G., I mafiusi di la vicaria di Palermo: scene popolari in tre atti, introduzione di S. Pedone, reprint, Palermo, 1994.

Romano, A., Storia del movimento socialista in Italia, Bocca, Milano, 1954.

Sceusa, F., Mafia ufficiale, Poche parole dell'ammonito Francesco Sceusa, Stabilimento Tipografico, Napoli, 1877.

Schneider, J. and P., Culture and Political Economy in Western Sicily, Academic press, New York, 1976.

Scialoja, A., I bilanci del regno di Napoli e degli stati sardi. Note e confronti, Guigoni, Torino, 1857.

Sciascia, L., Sicily as Metaphor; conversations presented by Marcelle Padovani, Marlboro press, Marboro Vt. 1994.

Seigel, J., Bohemian Paris. Culture, Politics and the Boundaries of Bourgeois Life 1830-1930, Viking, New York, 1986.

Shawcross, T., and M. Young, Men of honour: the confessions of Tommaso Buscetta, Collins, London, 1987.

Tajani, D., Discorso pronunziato alla Camera dei deputati nella discussione sui provvedimenti di pubblica sicurezza, 2 ed.. Lavagnino, Genova,1875.

Titone, V., Storia, mafia e costume in Sicilia, Edizioni del Milione, Milano, 1964.

Tobias, J.J., Crime and Industrial Society in the 19th century, Batsford, London, 1967.

Tombs, R., Crime and the Security of the State: the "Dangerous Classes" and Insurrection in 19th-century Paris, in V.A. C. Gatrell, B. Lenman, G. Parker, Crime and the Law: The Social History of Crime in Western Europe since 1500, Europa, London, 1980, p. 214-37.

Tommasi-Crudeli, C., La Sicilia nel 1871, Le Monnier, Firenze, 1871.

Tranfaglia, N., La mafia come metodo nell'Italia contemporanea, Laterza, Roma-Bari, 1991. Umiltà, A., Camorra e mafia, Notes sur l'Italie, James Attinger, Neuchâtel, 1878.

Vacca, G., Le mie prigioni 1840-50. Ricordi e impressioni, E. Consolo, Napoli, 1911.

Wiener, M., Recostructing the Criminal. Culture, Law and Politics in England 1830-1914, C.U.P., Cambridge, 1990. 